\title{
ERRATUM
}

\section{Erratum to: Cost-effectiveness of ticagrelor versus clopidogrel for the prevention of atherothrombotic events in adult patients with acute coronary syndrome in Germany}

Ulrike Theidel · Christian Asseburg •

Evangelos Giannitsis · Hugo Katus

Published online: 9 April 2013

(C) Springer-Verlag Berlin Heidelberg 2013

\section{Erratum to: Clin Res Cardiol}

DOI 10.1007/s00392-013-0552-7

In this publication affiliations were missing for all authors, and the conflict of interest statement was inaccurate. The authors' affiliations are as follows:

Ulrike Theidel

Herescon Gmbh, Königsworther Str. 2,

30167 Hannover, Germany

Christian Asseburg

ESiOR Oy, Tulliportinkatu 2LT4,

70100 Kuopio, Finland

Evangelos Giannitsis and Hugo Katus

Department of Medicine III, University of Heidelberg,

Im Neuheimer Feld 162, 69120 Heidelberg, Germany

The following conflict of interest statement was missing from the original publication: $\mathrm{CA}$ is an employee and shareholder of ESiOR Oy.

The online version of the original article can be found under doi:10.1007/s00392-013-0552-7.

\footnotetext{
U. Theidel $(\bowtie)$

Herescon Gmbh, Königsworther Str. 2,

30167 Hannover, Germany

e-mail: theidel@herescon.com

C. Asseburg

ESiOR Oy, Tulliportinkatu 2LT4, 70100 Kuopio, Finland

E. Giannitsis · H. Katus

Department of Medicine III, University of Heidelberg,

Im Neuheimer Feld 162, 69120 Heidelberg, Germany
} 